8-1995

\title{
Brand Capital and Incumbent Firms' Positions in Evolving Markets
}

Louis A. Thomas

University of Pennsylvania

Follow this and additional works at: http://repository.upenn.edu/mgmt_papers

Part of the Business Administration, Management, and Operations Commons

\section{Recommended Citation}

Thomas, L. A. (1995). Brand Capital and Incumbent Firms' Positions in Evolving Markets. The Review of Economics and Statistics, 77 (3), 522-534. http://dx.doi.org/10.2307/2109912 


\title{
Brand Capital and Incumbent Firms' Positions in Evolving Markets
}

\begin{abstract}
In many advertising-intensive industries one observes market share persistence, i.e., firms maintaining lead market shares over long periods of time. I hypothesize that firms that have the largest stock of well-established brands, a stock that I term brand capital, are most likely to introduce new products in response to new market information about consumer preferences. Firms with less brand capital delay their introductions until the uncertainty concerning the market size is reduced. I present empirical support in a study of new product introductions in the U.S. beverage industry.
\end{abstract}

\section{Disciplines}

Business Administration, Management, and Operations 


\title{
BRAND CAPITAL AND INCUMBENT FIRMS' POSITIONS IN EVOLVING MARKETS
}

\author{
Louis A. Thomas*
}

\begin{abstract}
In many advertising-intensive industries one observes market share persistence, i.e., firms maintaining lead market shares over long periods of time. I hypothesize that firms that have the largest stock of well-established brands, a stock that I term brand capital, are most likely to introduce new products in response to new market information about consumer preferences. Firms with less brand capital delay their introductions until the uncertainty concerning the market size is reduced. I present empirical support in a study of new product introductions in the U.S. beverage industry.
\end{abstract}

\section{Introduction}

$\mathrm{H}$ OW is it that some firms are able consistently to outperform competitors in profitability and market share? Given that consumer tastes and technologies evolve over time, one potential source of persistent advantage is the ability to be first to market new products successfully. While a relationship has been documented between the order of entering new markets and the share subsequently sustained, there is little understanding of which firms first offer new products. Robinson and Fornell (1985), who found persistent share advantage among first entries in a sample of 371 mature consumer goods businesses, attribute this phenomenon partly to Schmalensee's (1982) theoretical finding that later entering brands are at a disadvantage when consumers are uncertain about the quality of new products. A subsequent study by Urban et al. (1986) found that order of entry explained a significant amount of the variation in market share for a sample of 47 new brands across twelve product categories.

There is some evidence which suggests that the ability to maintain share leadership is much stronger in advertising intensive industries than others. According to Advertising Age, of the top twenty-five consumer brands that were sold in 1923, nineteen were still share leaders in 1983. Four brands fell to number two position, one to number three, and one to fifth. ${ }^{1}$ Sutton (1991) finds evidence that the endogeneity of advertising

Received for publication March 9, 1993. Revision accepted for publication May 16, 1994.

* University of Pennsylvania. expenditures places a lower bound on concentration in the food and drink group.

I wish to develop the idea that there exists a firm-specific asset, which I term brand capital, that rests in goodwill accrued by the firm's existing brands. This goodwill explains why firms with high values of brand capital are most likely to introduce new products first, those with less brand capital wait and enter only if the market size is sufficiently large.

As markets for new product varieties arise or are perceived, some are large and can accommodate many entrants; small new markets can accommodate only a few. I will show that firms with high levels of brand capital introduce products in both large and small new markets, those with low levels of brand capital only in large markets. Thus, the high brand capital firm can maintain a higher share than its low brand capital rivals even as consumer tastes change. This offers a possible explanation for the share persistence phenomenon in advertising-intensive industries.

There has been some work on brand-related goodwill in the economics literature. Wernerfelt and Sappington (1985) developed a model whereby two firms that have a brand image in one market introduce a new product along a linear city. In addition to the traditional transportation cost, each consumer faces an image cost. The further away the new product is from the original brand's image, the more uncertain the consumer is of the new brand's quality. Thus, firms have an incentive to introduce new brands "close" to the image of the original product. The authors also present some evidence that suggests that the further away a firm places a new brand from the original, the less likely it is to use the name of the original brand. Wernerfelt (1988) shows that brand names can be used as a signal of high quality.

Raubitschek (1988) develops a model in which firms introduce more products as the probability of product success increases. The concept of brand capital suggests that firms with more brand capital will not only introduce more products but

${ }^{1}$ Advertising Age, September 19, 1983. 
also introduce early. Schmalensee (1978) develops a model where existing firms introduce new brands in order to limit outside entry. While brand capital does not deal with entry deterrence, it does explain the entry order of new incumbent brands.

In this paper, I show that in the beer, soft drink, and coffee industries, the firms most likely to enter new products first in response to new information about consumer tastes are those with the most brand capital.

\section{Development of Hypotheses}

I now wish to develop three testable hypotheses of brand capital and entry order. Consider three different brands about a circular city. Two brands are owned by, say, firm A and one is owned by firm B. The true distribution of demand, which need not be uniform, is not known to either firm. Each firm initially has the same estimate and locates its brands around the circle through an unspecified process which does not influence what happens subsequently. ${ }^{2}$ The three incumbent brands are sunk. At some time new information arrives which causes each firm to increase its estimate of the number of consumers located near a given point. The new information may concern preferences of new demanders. The incumbents get random but sequential opportunities to introduce brands at new locations on the basis of uncertain new information.

All new brands are experience goods for buyers, who are correctly informed about the distance of the claimed attributes of the new brand from established brands. Now consider a model of pioneering brands as in Schmalensee (1982). Consumers discount the utility from brands which they have not tried. The size of this discount decreases with the closeness of the new brand to the same firm's existing brand which the consumer has either tried or gained word-of-mouth recommendations. The consumer's lowered discount can be justified on the ground that the firm would not find it profitable to deliberately introduce a bad brand for fear of destroying goodwill on its existing brand.

Each firm can introduce a new brand which is associated or identified with one of its existing

\footnotetext{
${ }^{2}$ I assume that firm A disperses its brands.
}

brands. This association can be accomplished through what is known in marketing parlance as a brand extension: a new product which uses the brand name of an existing brand. For reasons discussed above, consumers are more likely to try new products which bear familiar brand names because they believe that such products are more likely to deliver the promised attributes. ${ }^{3}$ Because firm A has more existing brands than firm B by assumption, one of its brands is likely the nearest on the circle to some point about which the firms receive new information (equally likely to come from any point on the circle). From these assumptions the following testable behavioral hypotheses follow.

i) The firm with the largest stock of existing brands (i.e., the firm's brand capital) expects to sell more units in any uncertain new market, so will enter some markets that other firms would skip as exceptionally unprofitable. Revealed market size will sometimes be larger than mean expectation, causing the subsequent entry by low capital firms. Thus the high-capital firm is the most likely first entrant.

ii) A low capital firm may enter first if the expected market size is large enough, but the probability that the high-capital firm enters second conditional on the lowcapital firm having entered first is greater than the probability that the low capital firm enters second conditional on the high capital firm entering first.

iii) A market with large expected size is both more likely to be roomy enough to attract a low capital first entrant and more likely to be profitable for multiple entrants.

Throughout the discussion I have ignored price competition. To justify this assumption one can invoke models of vertical product differentiation, in which products of equal quality enter the market at the same price. Such a model seems consistent with the pricing practice in the brewing, soft drink, and coffee industries. High quality products such as premium beer and coffee carry simi-

\footnotetext{
${ }^{3}$ There is some theoretical and empirical support for this pattern of buying behavior. Aaker and Keller (1990) measured how consumers form attitudes towards brand extensions and found that consumer valuations were higher the closer the "fit" between the original brand and the extension.
} 
lar (high) prices, but one observes very little price competition among them.

I chose to test my hypotheses about brand capital and entry in the brewing, coffee, and soft drink industries for several reasons. First, because many well-established brands are heavily advertised seemingly in order to maintain consumer goodwill, I wanted industries with high advertising to sales ratios. Beer, coffee, and soft drinks are highly advertised. Also, I wanted industries that spend little on $\mathrm{R} \& \mathrm{D}$, which would inject variation in entry sequences due to innovative effort or success. Finally, the introduction of new products evidently occurs in response to new information about demand, e.g., new product activity in the food and drink sector over the last two decades partly due to heightened interest in health and nutrition. ${ }^{4}$

\section{Model Specification and Estimation Procedure}

If firm $i$ enters at position $p$ during some round of new product introductions, let its profits be given by the following expression:

$$
\Pi_{i p}=q_{i p}(r-c)-F
$$

where $q_{i p}$ is firm $i$ 's unit sales if it enters at position $p, r$ is the price, $c$ is unit costs, and $F$ is the fixed entry cost. Since profits are not directly observable I define a latent variable $y_{i p}$, which is firm $i$ 's propensity to enter at position $p$. I will estimate $y_{i p}$ using a rank ordered logit technique as described in Hausman and Ruud (1987). Let $y_{i p}$ be given by the following expression:

$$
\begin{aligned}
y_{i p} & =q_{i p} \beta-\gamma F+\epsilon_{i p} \\
p & =1, \ldots, P .
\end{aligned}
$$

\footnotetext{
${ }^{4}$ As long as consumers choose product largely by brand name and not price there is no efficiency or business stealing effect. The introduction of a new nearby product does not force the firm to lower the price of its existing products. This is consistent with the highly inelastic demand of products in the food and drink group. As long as the updated market size is large enough to accommodate a new product, no incumbent can delay a new product from entering by choosing not to introduce itself. In particular, in a two period game, there exists no Nash equilibrium where the incumbent chooses to delay introduction in period one in order to preserve profits from his existing product line. The entrant would choose to enter during period one. Given this, the incumbent would earn greater profits by introducing during period one. Thus there is no disincentive to introduce due to a replacement or cannibalization effect.
}

$\beta$ is a $P$-vector of weights on unit sales and $\gamma$ is also a $P$-vector of weights on the fixed cost. The term $(r-c)$ is incorporated into $\beta$. I assume that the $\epsilon_{i p}$ is a randomly distributed disturbance term with a logistic distribution. Thus the probability that firm $i$ enters at the $P^{\text {th }}$ position instead $1, \ldots, P-1$ is

$$
\begin{aligned}
& F_{i P}\left[q_{i 1}, \ldots, q_{i P}, F ; \beta, \gamma\right] \\
& \quad=\exp \left(q_{i p} \beta+\gamma F\right) /\left[\sum_{p=1}^{P} \exp \left(q_{i p} \beta+\gamma F\right)\right] .
\end{aligned}
$$

The probability that firm $i$ has a choice ordering $r_{i}$ of $1, \ldots, P$ where 1 is preferred to 2 etc. is given by the following expression:

$$
\begin{aligned}
\operatorname{Pr}\left(r_{i}, q_{i p}, F ; \beta, \gamma\right) & \\
& =\prod_{p=2}^{P} F_{i P-p+1}\left[q_{i P}, \ldots, q_{i P-p+1}, F ; \beta, \gamma\right] .
\end{aligned}
$$

With the independence of irrelevant alternatives assumed (IIA) the above is simply the product of $P-1$ logit likelihood functions. If there are $N$ firms then the likelihood function is given by

$$
L(\beta, \gamma)=\prod_{i=1}^{N} \log \left[\operatorname{Pr}\left(r_{i}, q_{i}, F ; \beta, \gamma\right)\right] .
$$

The maximum likelihood estimate is the maximizer of $L(\beta, \gamma)$.

\section{Variables and Definitions}

\section{A. Brand Capital}

In order to estimate the model I need proxies for $q_{i p}$ and $y_{i p}$. The earlier discussion suggests that the quantity a firm sells is a function of the distance of its nearest brand from the location of its new product. The more established brands the firm has, the shorter this distance is likely to be. Thus the number of units that the firm expects to sell is proportional to its number of well-established brands, which I will thus use as a proxy for $q_{i p}$. Henceforth I will refer to the number of well-established brands as the firm's "brand capital" and to established brands as "capital brands." Previous studies of consumer package goods industries, e.g., Raubitschek (1988), suggest that a brand is well established if it has survived for at least five years on the market. As the products examined in my study exhibit similar frequencies 
of purchase, I employ this same rule. A brand introduced in year $t$ and still offered in years $t+1, \ldots, t+5$ is thus a capital brand.

\section{B. Order of Entry}

The model defines a round of new product introductions as a sequence of brands of a new product introduced by incumbent firms. The order of entry was determined for each round on the basis of the date each brand was nationally introduced, the brand with the earliest date being first, the one with the next earliest being second, and so forth. The actual order of entry will be used as a proxy for $y_{i p}$ in the following fashion. Given $N$ incumbent firms in the industry, the number of alternative entry choices are as follows:

$0=$ if the firm did not introduce a product during the round

$1=$ if the firm was the first to introduce

$2=$ if the firm was second to introduce

$N=$ if the firm was last to introduce.

Thus for the $P-1$ logits, for example, $y_{i p}=1$ if firm $i$ enters in the $P^{\text {th }}$ position and zero otherwise. The rank ordered logit technique allows the logits to be estimated jointly.

Each firm's capital brands were determined separately each round and measured as a proportion of total number of capital brands of the $N$ incumbents.

\section{Market Segments}

The three hypotheses assume that consumers are familiar with established products of similar attributes. In order to measure brand capital and determine the new product rounds I need to define groups of products with similar attributes. I will call these groups market segments and measure a firm's number of established brands, i.e., its brand capital, in each segment. New information gives rise to markets for new product varieties within the segments. Each industry segment is treated separately. Thus, the introduction of light beer in the popular priced segment is treated as a different round from the introduction of light beer in the super premium or premium segments.

In the brewing industry the above assumption holds for two reasons. First, the segments exhibit strong vertical differentiation. It is likely that consumers who have higher incomes shop among the more expensive beers, others may confine their search to those which are less expensive. Second, advertisers deliberately target their products to different groups of potential buyers using different media, so that consumers obtain the most information on the brands within a segment. I argue that this pattern suggests four segments in the beer industry. Popular beers are priced lowest and targeted at large-volume consumers, premium beers are priced in the mid-range, super premium beers are priced highest and targeted at upscale drinkers who also consume expensive imported beers, and malt, which is higher than others in alcohol content, is targeted at college students and ethnic drinkers. Elzinga (1986) supports this segmentation. He finds beer drinking to be highly image conscious and price elasticity to be very high within segments, but low between them. The soft drink industry is segmented by product type, of which I identified four: colas; lemon-lime; root beer; and orange. Consumers can easily discern that these products are physically different. Manufacturers of lemon-lime soft drinks typically address their advertising to consumers who do not like colas. While each of these segments might be further divided (e.g., diet colas or diet lemon-lime), the prevalence of common brand names suggests that products in these subsegments are selected on the basis of a common set of goodwill assets and brand names. Thus, for purposes of testing the hypotheses I do not see a need to treat these as separate segments. I identified two segments in the coffee industry: instant and regular. These two product types are very different, not only in taste, but also in terms of production process, production of instant coffee being much more capital-intensive. In addition, since manufacturers also advertise regular coffee as the higher quality product, this would suggest an element of vertical integration.

Data on introductions of new products were obtained from Predicasts F \& S Index, which covers several industry trade journals, and supplemented and confirmed using data supplied by Marketing Intelligence Inc., which covers more than 50 trade journals and employs a network of more than 200 field agents who monitor new product introductions in the United States. Information on market shares was obtained from an- 
nual issues of Advertising Age and The Beverage Industry Annual Manual. Only products introduced nationally were included, and, thus only firms that offered at least one national brand are represented. Year and month of introduction were determined for each new product.

\section{Single Industry Analysis}

To conserve space I will present detailed results only for the brewing industry and the pooled sample. More detailed results for the other industries are available upon request. The mean levels of relative brand capital were 0.03 for the brewing, soft drink and coffee industries. The standard deviations ranged from 0.07 for coffee to 0.08 for beer.

Table 1 gives the share of capital brands for the various brewers in each segment for 1980 and 1990.

Although some firms lack well-established brands in some segments, most have introduced new brands in these segments. For example, neither Miller or Anheuser Busch has a well-established malt beer, each having introduced beers in this segment unsuccessfully, and limited to regional distribution. Both Heilemann and Pabst have tried to introduce both premium and super premium beers, and Coors recently entered the popular priced segment with a new beer called Keystone. Thus, most firms are active in all segments even though they may not have a wellestablished brand in each segment.

A new product round began when a new beer type was introduced. I then determined when other firms introduced new beer products of this type (see table 2). I identified a total of 18 new product rounds (a total of 40 new products) in the beer industry between 1972 and April 1991. Of the 18 new product rounds all but 2 were led by firms introducing product extensions, and out of the 40 new products all but 3 were extensions. This would suggest that the primary mechanism of affiliation is through the extension of a wellknown brand name.

Analysis of the soft drink and coffee industries proceeded much like that of the beer industry. ${ }^{5}$ The 4 soft drink segments and 2 coffee segments were treated separately. There were a total of 14 new product rounds in the soft drink industry and 16 in coffee. ${ }^{6}$

\section{Testing the Hypotheses}

\section{A. Entry Order}

The results from the brewing industry are reported in table 3. The estimated coefficient for the first entry position is positive and significant. This result is consistent with the first maintained hypothesis that the greater the capital a firm has, the more likely it will enter in the first position rather than any other position. The estimated coefficients for the other positions are also positive. The coefficients decline for later entries. This suggests that if the high capital firm does

\footnotetext{
${ }^{5}$ In the cola segment there were seven rounds: diet caffeine free, caffeine free, fruit flavored, aspartame-saccharin mix, $100 \%$ Nutra Sweet, salt free, and calcium. In the lemon-lime segment there were three rounds: aspartame, fruit added, and fruit flavored. In the root beer segment there were two rounds: aspartame and cream flavored. Finally, in the orange segment: aspartame and fruit added.

${ }^{6}$ In the instant segment: freeze dried, decaffeinated, flavored, chicory, custom blends, Nutrasweet, premium, ice coffees. In the regular segment: decaffeinated, economy, economy decaffeinated, premium decaffeinated, custom blends, flavored, premium, and fast roast.
}

TABle 1.-Share of Brand Capital $(\%)$ BEER

\begin{tabular}{|c|c|c|c|c|c|c|c|c|}
\hline & \multicolumn{2}{|c|}{ Malt } & \multicolumn{2}{|c|}{ Premium } & \multicolumn{2}{|c|}{ Super Premium } & \multicolumn{2}{|c|}{ Popular Priced } \\
\hline & 1980 & 1990 & 1980 & 1990 & 1980 & 1990 & 1980 & 1990 \\
\hline Anheuser & 0 & 0 & 43 & 36 & 100 & 75 & 0 & 0 \\
\hline Miller & 0 & 14 & 29 & 18 & 0 & 25 & 0 & 3.7 \\
\hline Coors & 0 & 0 & 14 & 27 & 0 & 0 & 0 & 0 \\
\hline Stroh & 20 & 29 & 14 & 18 & 0 & 0 & 12.5 & 26 \\
\hline Heilemann & 40 & 43 & 0 & 0 & 0 & 0 & 12.5 & 41 \\
\hline Pabst & 20 & 14 & 0 & 0 & 0 & 0 & 25 & 30 \\
\hline Schlitz & 20 & - & 0 & - & 0 & - & 19 & - \\
\hline Olympia & 0 & - & 0 & - & 0 & - & 25 & - \\
\hline Schaefer & 0 & - & 0 & - & 0 & - & 6.3 & - \\
\hline
\end{tabular}


TAble 2.-Beer Industry New Product Rounds-1972-1991

\begin{tabular}{|c|c|c|c|c|c|}
\hline Segment & Product & Lead Firm & Product & Affiliation & Year \\
\hline \multirow[t]{3}{*}{ Malt } & Malt Coolers & Heilemann & La Croix & Extension $^{\mathrm{a}}$ & 1985 \\
\hline & Non-Alcoholic & Stroh & Barbican & Extension $^{\mathrm{b}}$ & 1986 \\
\hline & Dry & Heilemann & Colt 45 Dry & Extension & 1986 \\
\hline \multirow[t]{6}{*}{ Premium } & Low Calorie & Miller & Miller Lite & Extension & 1975 \\
\hline & Dry & Anheuser & Bud Dry & Extension & 1989 \\
\hline & Low Alcohol & Anheuser & LA & $\begin{array}{l}\text { Indirect } \\
\text { Affiliation }^{c}\end{array}$ & 1984 \\
\hline & Cold Filtered & Miller & Genuine Draft & Extension & 1985 \\
\hline & $\begin{array}{l}\text { Low Calorie } \\
\text { Cold Filtered }\end{array}$ & Miller & $\begin{array}{l}\text { Genuine Draft- } \\
\text { Light }\end{array}$ & Extension & 1989 \\
\hline & No Alcohol & Anheuser & O'Douls & $\begin{array}{l}\text { Indirect } \\
\text { Affiliation }^{c}\end{array}$ & 1989 \\
\hline \multirow[t]{4}{*}{$\begin{array}{l}\text { Super } \\
\text { Premium }\end{array}$} & Low Calorie & Anheuser & Michelob Light & Extension & 1978 \\
\hline & Dark & Anheuser & $\begin{array}{l}\text { Michelob- } \\
\text { Classic Dark }\end{array}$ & Extension & 1984 \\
\hline & Dry & Anheuser & Michelob Dry & Extension & 1988 \\
\hline & Cold Filtered & Anheuser & Michelob Draft & Extension & 1991 \\
\hline \multirow{5}{*}{$\begin{array}{l}\text { Popular } \\
\text { Priced }\end{array}$} & Low Alcohol & Heilemann & Old Style LA & Extension & 1984 \\
\hline & Low Calorie & Schlitz & Schlitz Lite & Extension & 1976 \\
\hline & Dry & Heilemann & Old Style Dry & Extension & 1988 \\
\hline & Dark & Heilemann & $\begin{array}{l}\text { Special Export } \\
\text { Dark }\end{array}$ & Extension & 1986 \\
\hline & No Alcohol & Heilemann & $\begin{array}{l}\text { Black Label } \\
\text { Non-Alcoholic } \\
\text { Malt Beverage }\end{array}$ & Extension $^{\mathrm{d}}$ & 1985 \\
\hline
\end{tabular}

not enter first, it is next most likely to enter second, and if not second then third. Equivalently, given that the firm with the highest capital enters first, the firm with the next highest capital is most likely to enter second than in any other position. The firm with the next highest capital is then more likely to enter third than in any other position. This result is also consistent with the maintained hypothesis.

The results for the soft drink industry conform to the hypothesis only in part. The greater the capital the more likely a firm is to enter in the first position rather than any other position. The coefficients for later entries, however, are higher than they are for the first. In the soft drink industry, the firm that has the largest share of capital brands introduced first only $43 \%$ of the time. Much of the nonconformance occurs in the cola segment, in which Royal Crown stands out as a very innovative firm, being first with a diet soft drink, and first with caffeine-free diet and saltfree drinks. In addition, it does not appear that these new products emerged nearer Royal Crown's products than Coke's or Pepsi's. Thus Royal Crown's strategy is not explained by the hypothesis. $^{7}$

The slope coefficients for the coffee industry are positive and significant, and their magnitudes decline with entry position. The results are consistent with the first hypothesis, although the difference between the first and second entry coefficients is small. Finally, I combine the data for a pooled estimation. The coefficients for the first, second, third, and fourth entry positions are positive and significant. In addition, the magnitude of the coefficients are suggested by the hypothesis.

It is possible that the IIA assumption does not hold. This would be true if firms decided on later entry by means of a different decision process not

\footnotetext{
${ }^{7}$ Whatever Royal Crown's strategy it has not improved its performance. Its market share has declined from nearly $7 \%$ of the cola market in the early 1970s to just over $2 \%$ in 1990.
} 
TABle 3.-Test for Brand CaPital-Order of Entry EfFect

\begin{tabular}{|c|c|c|c|c|c|c|c|}
\hline & 1 & 2 & 3 & 4 & 5 & 6 & 7 \\
\hline & \multicolumn{7}{|c|}{$\underline{\text { Beer }}$} \\
\hline Constant & $\begin{array}{c}-1.89^{\mathrm{a}} \\
(0.20)\end{array}$ & $\begin{array}{r}-1.92^{\mathrm{a}} \\
(0.20)\end{array}$ & $\begin{array}{r}-2.33^{\mathrm{a}} \\
(0.24)\end{array}$ & $\begin{array}{c}-3.28^{\mathrm{a}} \\
(0.38)\end{array}$ & $\begin{array}{c}-3.69^{\mathrm{a}} \\
(0.47)\end{array}$ & $\begin{array}{r}-5.63^{\mathrm{a}} \\
(1.17)\end{array}$ & $\begin{array}{r}-5.20^{\mathrm{a}} \\
(1.00)\end{array}$ \\
\hline Capital & $\begin{array}{r}6.29^{\mathrm{a}} \\
(1.20)\end{array}$ & $\begin{array}{r}4.21^{\mathrm{a}} \\
(1.37)\end{array}$ & $\begin{array}{r}3.01^{\mathrm{b}} \\
(1.83)\end{array}$ & $\begin{array}{c}1.77 \\
(3.38)\end{array}$ & $\begin{array}{c}0.03 \\
(5.52)\end{array}$ & $\begin{array}{c}5.39 \\
(5.01)\end{array}$ & $\begin{array}{c}-249.49^{\mathrm{c}} \\
(45727)\end{array}$ \\
\hline \multirow{3}{*}{ Long Likelihood } & 18 & 11 & 6 & 2 & 1 & 1 & 1 \\
\hline & -367.57 & & & & & & \\
\hline & \multicolumn{7}{|c|}{$\underline{\text { Soft Drinks }}$} \\
\hline Constant & $\begin{array}{r}-1.68^{\mathrm{a}} \\
(0.18)\end{array}$ & $\begin{array}{c}-1.98^{\mathrm{a}} \\
(0.21)\end{array}$ & $\begin{array}{r}-2.63^{\mathrm{a}} \\
(0.28)\end{array}$ & $\begin{array}{r}-4.07^{\mathrm{a}} \\
(0.53)\end{array}$ & $\begin{array}{r}-3.79^{\mathrm{a}} \\
(0.49)\end{array}$ & $\begin{array}{r}-5.22^{\mathrm{a}} \\
(1.00)\end{array}$ & $\begin{array}{c}-5.22 \\
(1.00)\end{array}$ \\
\hline Capital & $\begin{array}{r}6.31^{\mathrm{a}} \\
(1.61)\end{array}$ & $\begin{array}{r}6.46^{\mathrm{a}} \\
(1.73)\end{array}$ & $\begin{array}{r}8.13^{\mathrm{a}} \\
(1.86)\end{array}$ & $\begin{array}{l}11.04^{\mathrm{a}} \\
(2.45)\end{array}$ & $\begin{array}{c}3.57 \\
(4.77)\end{array}$ & $\begin{array}{c}-131.96^{c} \\
(36506)\end{array}$ & $\begin{array}{c}-131.96^{c} \\
(36506)\end{array}$ \\
\hline \multirow{3}{*}{ Log Likelihood } & 14 & 11 & 9 & 5 & 4 & 0 & 0 \\
\hline & -365.63 & & & & & & \\
\hline & \multicolumn{7}{|c|}{ Coffee } \\
\hline Constant & $\begin{array}{c}-1.84 \\
(0.19)\end{array}$ & $\begin{array}{c}-2.07^{\mathrm{a}} \\
(0.21)\end{array}$ & $\begin{array}{r}-2.38^{\mathrm{a}} \\
(0.25)\end{array}$ & $\begin{array}{r}-3.16^{\mathrm{a}} \\
(0.37)\end{array}$ & $\begin{array}{r}-3.52^{\mathrm{a}} \\
(0.45)\end{array}$ & $\begin{array}{r}-5.13^{\mathrm{a}} \\
(1.00)\end{array}$ & $\begin{array}{r}-5.14^{\mathrm{a}} \\
(1.00)\end{array}$ \\
\hline Capital & $\begin{array}{c}7.06^{\mathrm{a}} \\
(1.43)\end{array}$ & $\begin{array}{c}6.54^{\mathrm{a}} \\
(1.53)\end{array}$ & $\begin{array}{r}4.31^{\mathrm{a}} \\
(2.03)\end{array}$ & $\begin{array}{r}-4.16 \\
(8.67)\end{array}$ & $\begin{array}{c}-254.12^{c} \\
(61013)\end{array}$ & $\begin{array}{c}-221.35^{\mathrm{c}} \\
(57344)\end{array}$ & $\begin{array}{l}-21.35^{\mathrm{c}} \\
(57344)\end{array}$ \\
\hline \multirow{3}{*}{$\begin{array}{l}\text { Number of Entries } \\
\text { Log Likelihood }\end{array}$} & 16 & 14 & 7 & 1 & 0 & 0 & 0 \\
\hline & -365.04 & & & & & & \\
\hline & \multicolumn{7}{|c|}{ Pooled } \\
\hline Constant & $\begin{array}{r}-4.43^{\mathrm{a}} \\
(0.46)\end{array}$ & $\begin{array}{r}-3.58^{\mathrm{a}} \\
(0.38)\end{array}$ & $\begin{array}{r}-3.61^{\mathrm{a}} \\
(0.42)\end{array}$ & $\begin{array}{r}-4.72^{\mathrm{a}} \\
(0.69)\end{array}$ & $\begin{array}{r}-3.69^{\mathrm{a}} \\
(0.54)\end{array}$ & $\begin{array}{r}-5.74^{\mathrm{a}} \\
(1.41)\end{array}$ & $\begin{array}{r}-4.81^{\mathrm{a}} \\
(1.00)\end{array}$ \\
\hline Capital & $\begin{array}{l}15.62^{\mathrm{a}} \\
(1.74)\end{array}$ & $\begin{array}{l}12.05^{\mathrm{a}} \\
(1.62)\end{array}$ & $\begin{array}{l}10.20^{\mathrm{a}} \\
(1.79)\end{array}$ & $\begin{array}{l}10.60^{\mathrm{a}} \\
(2.61)\end{array}$ & $\begin{array}{c}-0.04 \\
(4.67)\end{array}$ & $\begin{array}{c}4.70 \\
(7.94)\end{array}$ & $\begin{array}{c}-253.30^{c} \\
(32918)\end{array}$ \\
\hline $\begin{array}{l}\text { Number of Entries } \\
\text { Log Likelihood }\end{array}$ & $\begin{array}{c}48 \\
-29473\end{array}$ & 36 & 22 & 8 & 5 & 1 & 1 \\
\hline & -294.13 & & & & & & \\
\hline
\end{tabular}

encompassed by the model. If this is true it may account for the fact that coefficients for later entry are lower than for earlier entry. In order to test this I use a Hausman (1978) significance test based on the log likelihood functions. Again, assume there are $P$ entry choices and $N$ firms.

$$
L(\beta, \gamma)
$$$$
=\sum_{n=1}^{N} \sum_{p=2}^{r} \log \left[F_{P-p+1}\left[q_{P}, \ldots, q_{P-p+1}, F ; \beta, \gamma\right]\right]
$$$$
+\sum_{n=1}^{N} \sum_{p=r}^{P} \log \left[F_{P-p+1}\left[q_{P}, \ldots, q_{P-p+1}, F ; \beta, \gamma\right]\right]
$$

or,

$L(\beta, \gamma)=L_{r}(\beta, \gamma)$

$+\sum_{n=1}^{N} \sum_{p=r}^{P} \log \left[F_{P-p+1}\left[q_{P}, \ldots, q_{P-p+1}, F ; \beta, \gamma\right]\right]$.
Table 4.- Hausman Specification Test

\begin{tabular}{cc}
\hline \hline Ranks $(r)$ & Likelihood Ratio \\
\hline 1 & 294.56 \\
2 & 219.68 \\
3 & 141.84 \\
4 & 64.64 \\
5 & 24.76 \\
6 & 0.12 \\
\hline
\end{tabular}

Let $\beta_{r^{*}}$ and $\gamma_{r^{*}}$ be the MLE of the second term on the right and $\beta_{r}$ and $\gamma_{r}$ be that for the first term. Then, $-2\left[L\left(\beta_{P-1}\right)-L_{r}\left(\beta_{r}, \gamma_{r}\right)-\right.$ $\left.L_{r^{*}}\left(\beta_{r^{*}}, \gamma_{r^{*}}\right)\right]$ has a chi-square distribution with $P$ degrees of freedom. One can estimate the statistic with increasing values of $r$. The results of this test are shown in table 4. The null that the coefficients decline because the model is misspecified is rejected at the $1 \%$ level up to the fifth 
rank (i.e., $r=5$ ), but not for the last position. The model might fail to describe the entry behavior of the firm that chooses to enter in the final position, although the small number of observations might instead be responsible.

In each segment there is a dominant firm, i.e., a firm with far more brand capital than any of its rivals. In the malt and the popular priced segments it is Heilemann; in the premium and super premium segments, Anheuser-Busch. Dominance poses a potential problem for the results presented in table 3 , which may be driven by the entry pattern of the dominant firm. For example, if the dominant firm enters first as expected, but the other firms enter in some random order, the empirical results would still conform to the first maintained hypothesis. If I were to omit from the sample the firms with the greatest share of capi- tal brands, and then reestimate the model, the results should not be statistically significant if I am only capturing the activity of those firms. I thus omitted in the malt and popular priced segments all new products introduced by Heilemann, in the premium and super premium segments, all products introduced by Anheuser Busch and reestimated the model. The results are presented in table 5. Again, the results from the beer industry are consistent with the maintained hypothesis. Firms with high capital are more likely to enter in the first position than any other position. In the soft drink industry, the results are qualitatively similar to those estimated earlier: while high capital firms are more likely to enter, they are not more likely to enter in the first position. In the coffee industry the estimated coefficients are positive and significant for the

Table 5.-Brand Capital and Entry Order Segment Share Leader OMitTed

\begin{tabular}{|c|c|c|c|c|c|c|}
\hline & 1 & 2 & 3 & 4 & 5 & 6 \\
\hline & \multicolumn{6}{|c|}{$\underline{\text { Beer }}$} \\
\hline Constant & $\begin{array}{r}-1.84^{\mathrm{a}} \\
(0.20)\end{array}$ & $\begin{array}{r}-2.26^{\mathrm{a}} \\
(0.24)\end{array}$ & $\begin{array}{r}-3.29^{\mathrm{a}} \\
(0.39)\end{array}$ & $\begin{array}{r}-3.68^{\mathrm{a}} \\
(0.48)\end{array}$ & $\begin{array}{r}-5.82^{\mathrm{a}} \\
(1.34)\end{array}$ & $\begin{array}{r}-5.17^{\mathrm{a}} \\
(1.00)\end{array}$ \\
\hline Capital & $\begin{array}{r}5.86^{\mathrm{a}} \\
(1.73)\end{array}$ & $\begin{array}{l}3.66 \\
(2.36)\end{array}$ & $\begin{array}{l}2.95 \\
(3.97)\end{array}$ & $\begin{array}{c}0.68 \\
(6.19)\end{array}$ & $\begin{array}{c}8.88 \\
(7.23)\end{array}$ & $\begin{array}{c}-284.64^{\mathrm{c}} \\
(82172)\end{array}$ \\
\hline \multirow[t]{2}{*}{ Log Likelihood } & $\begin{array}{c}12 \\
-252.76\end{array}$ & 6 & 2 & 1 & 1 & 0 \\
\hline & \multicolumn{6}{|c|}{$\underline{\text { Soft Drinks }}$} \\
\hline Constant & $\begin{array}{r}-1.91^{\mathrm{a}} \\
(0.20)\end{array}$ & $\begin{array}{r}-2.56^{\mathrm{a}} \\
(0.27)\end{array}$ & $\begin{array}{r}-4.13^{\mathrm{a}} \\
(0.57)\end{array}$ & $\begin{array}{r}-3.81^{\mathrm{a}} \\
(0.50)\end{array}$ & $\begin{array}{c}-5.21 \\
(1.00)\end{array}$ & $\begin{array}{r}-5.21^{\mathrm{a}} \\
(1.00)\end{array}$ \\
\hline Capital & $\begin{array}{r}0.11^{\mathrm{a}} \\
(2.05)\end{array}$ & $\begin{array}{l}10.29^{\mathrm{a}} \\
(2.31)\end{array}$ & $\begin{array}{l}14.53^{\mathrm{a}} \\
(3.20)\end{array}$ & $\begin{array}{c}5.82 \\
(5.28)\end{array}$ & $\begin{array}{l}-140.1^{c} \\
(47241)\end{array}$ & $\begin{array}{r}-140.1^{c} \\
(47241)\end{array}$ \\
\hline \multirow[t]{2}{*}{$\begin{array}{l}\text { Number of Entries } \\
\text { Log Likelihood }\end{array}$} & $\begin{array}{c}13 \\
-237.79\end{array}$ & 10 & 5 & 4 & 0 & 0 \\
\hline & \multicolumn{6}{|c|}{ Coffee } \\
\hline Constant & $\begin{array}{r}-2.02^{\mathrm{a}} \\
(0.22)\end{array}$ & $\begin{array}{r}-2.25^{\mathrm{a}} \\
(0.24)\end{array}$ & $\begin{array}{r}-3.12^{\mathrm{a}} \\
(0.37)\end{array}$ & $\begin{array}{r}-3.48^{\mathrm{a}} \\
(0.45)\end{array}$ & $\begin{array}{r}-5.09^{\mathrm{a}} \\
(1.00)\end{array}$ & $\begin{array}{r}-5.09^{\mathrm{a}} \\
(1.00)\end{array}$ \\
\hline Capital & $\begin{array}{l}9.19^{\mathrm{a}} \\
(2.04)\end{array}$ & $\begin{array}{l}3.78 \\
(3.02)\end{array}$ & $\begin{array}{c}-4.76 \\
(9.53)\end{array}$ & $\begin{array}{l}-267.47^{c} \\
(10097)\end{array}$ & $\begin{array}{l}-240.92^{c} \\
(88785)\end{array}$ & $\begin{array}{l}-240.92^{c} \\
(88785)\end{array}$ \\
\hline Number of Entries & 15 & 7 & 1 & 0 & 0 & 0 \\
\hline \multirow[t]{2}{*}{ Log Likelihood } & -245 & & & & & \\
\hline & \multicolumn{6}{|c|}{ Pooled } \\
\hline Constant & $\begin{array}{c}-4.053^{\mathrm{a}} \\
(0.49)\end{array}$ & $\begin{array}{r}-3.35^{\mathrm{a}} \\
(0.41)\end{array}$ & $\begin{array}{r}-4.99^{\mathrm{a}} \\
(0.81)\end{array}$ & $\begin{array}{r}-3.74^{\mathrm{a}} \\
(0.55)\end{array}$ & $\begin{array}{r}-5.89^{\mathrm{a}} \\
(1.52)\end{array}$ & $\begin{array}{r}-4.83^{\mathrm{a}} \\
(1.00)\end{array}$ \\
\hline Capital & $\begin{array}{l}17.09^{\mathrm{a}} \\
(2.32)\end{array}$ & $\begin{array}{l}11.05^{\mathrm{a}} \\
(2.20)\end{array}$ & $\begin{array}{l}14.08^{\mathrm{a}} \\
(3.67)\end{array}$ & $\begin{array}{c}1.25 \\
(5.01)\end{array}$ & $\begin{array}{c}7.04 \\
(9.17)\end{array}$ & $\begin{array}{c}-265.52^{c} \\
(41672)\end{array}$ \\
\hline $\begin{array}{l}\text { Number of Entries } \\
\text { Log Likelihood }\end{array}$ & $\begin{array}{c}40 \\
-203.69\end{array}$ & 23 & 8 & 5 & 1 & 1 \\
\hline
\end{tabular}

Note: Standard errors are in parentheses.

${ }^{a}$ Significant at the $5 \%$ level.

${ }^{\mathrm{b}}$ Significant at the $10 \%$ level.

${ }^{c}$ Estimate did not converge. 
first entry position. The results from the pooled data set are fully consistent with the first hypothesis.

\section{B. Conditional Entry Order}

The preceding tests address the first hypothesis: the high brand capital firm is most likely to enter first. While the results are consistent with it, they are also consistent with a number of other hypotheses. In particular, any firm-specific asset that is correlated with brand capital (e.g., market share or distribution costs) could yield the same result. The key feature that will distinguish my hypothesis from these alternatives is that the latter imply that the firms always enter in the same order with some stochastic error, while the former explains under what conditions the order of entry may vary. I hope to show that the second and third hypotheses distinguish my model from these alternatives.

The second hypothesis holds that the probability of a firm with high brand capital entering second conditional on its rival having already introduced a product is greater than the probability of a low brand capital firm introducing conditional on a high brand capital firm's prior introduction. I can test this proposition by means of the entry sequences I have identified. Specifically, I measure the number of times a firm that did not begin the sequence nonetheless introduced a product during the sequence. For each firm, I count the number of sequences in which the firm was not the first to enter and the number of times that firm introduced a new brand at any point in these sequences. Dividing these two numbers yields the percentage of times the firm introduced conditional on not having entered first.

The results for the three industries are presented in table 6 . The results for the brewing industry are consistent with the second hypothesis. The firm with the highest share of capital brands has the highest probability of entering given that it does not enter first. Using a chisquare test, for each segment of the brewing industry I can reject at the 5\% level the null hypothesis that the probabilities are equal.

The results for the soft drink industry are not as strong. In the cola segment, the hypothesis predicts that one should find Coca Cola and Pepsi with the highest probabilities. Instead it is
Royal Crown. In the lemon-lime segment the hypothesis suggests that Coca Cola should be ahead of $7 \mathrm{Up}$. In the root beer segment A \& W should be ahead of Crush, and in orange either Cadbury or Crush should be ahead of Coca Cola. The null hypothesis can be rejected only for the cola segment. The results for the instant coffee segment are as expected. General Foods leads Nestle and P\& G. In the regular segment the hypothesis would suggest that $P \& G$ be ahead of Nestle. This latter result is significant only at the $10 \%$ level. I also estimated the probabilities that a firm entered given that it did not enter first or second. ${ }^{8}$ I found that while the results in the brewing industry are consistent with the second maintained hypothesis, they are not significant. I again found that Royal Crown has a higher probability than Coca Cola or Pepsi of entering given that it did not enter first or second. The results from the coffee industry are as predicted. I also estimated the probability that a firm entered given that it did not enter first, second, or third. There are too few observations to draw any significant conclusions.

\section{Order of Entry and Expected Market Size}

The findings thus far bear on the first two hypotheses of brand capital. I now turn to the third hypothesis that the low capital firm may introduce first if the expected market size is large enough. If this hypothesis explains the data well, I should find that the firm with the highest share of capital brands is less likely to lead when the expected market size is large. Most importantly, this test, like the previous one, allows me to distinguish brand capital from firm heterogeneity. The assumption of firm heterogeneity yields no prediction about the order of entry of firms if the advantaged firm fails to enter first.

Because the expected market size for each of the rounds discussed cannot be observed directly I must use a proxy. The primary proxy for the expected market size is the number of firms that actually introduced a new product during a new product round. The larger the expected market size the more firms that find it profitable to enter with a new product. If one assumes that firms are right, on average, in their estimates of the market's

\footnotetext{
${ }^{8}$ These results are available upon request.
} 


\begin{tabular}{|c|c|c|c|c|}
\hline \multicolumn{5}{|c|}{$\begin{array}{l}\text { TABLE 6. - ProbabILITY THAT A FiRM ENTERED IN } \\
\text { IN WHICH IT DID Not ENTER FIRST }\end{array}$} \\
\hline & \multicolumn{4}{|c|}{ Beer } \\
\hline & Malt & Premium & Super Premium & Popular Priced \\
\hline Anheuser $^{c}$ & 0 & 100 & (a) & 0 \\
\hline Miller & 0 & 33.3 & 50 & 20 \\
\hline Coors & 0 & 66.7 & 0 & 0 \\
\hline Stroh & 50 & 33.3 & 0 & 20 \\
\hline Heilemann & 100 & 0 & 0 & 100 \\
\hline Pabst & 0 & 0 & 0 & 60 \\
\hline \multirow[t]{3}{*}{$x^{2}$ statistic } & $9.25^{b}$ & $10^{b}$ & $14^{\mathrm{a}}$ & $11.6^{\mathrm{a}}$ \\
\hline & \multicolumn{4}{|c|}{ Soft Drinks } \\
\hline & Cola & Lemon & Root Beer & Orange \\
\hline Coca Cola & 66.7 & 33.3 & 0 & 100 \\
\hline Pepsi & 71.4 & 66.7 & 50 & 50 \\
\hline $7 \mathrm{Up}$ & 50 & 50 & 0 & 0 \\
\hline Dr. Pepper & 57.1 & 0 & 0 & 0 \\
\hline Royal Crown & 80 & 0 & 0 & 0 \\
\hline Cadbury & 0 & 0 & 0 & 50 \\
\hline$A \& W$ & 0 & 0 & 100 & 0 \\
\hline Crush & 0 & 0 & 100 & 100 \\
\hline \multirow[t]{3}{*}{$\chi^{2}$ statistic } & $14.37^{\mathrm{a}}$ & 9.22 & 8.68 & 7.6 \\
\hline & \multicolumn{2}{|c|}{ Coffee } & & \\
\hline & Instant & Regular & & \\
\hline General Foods & 75 & 100 & & \\
\hline Procter \& Gamble & 25 & 40 & & \\
\hline Nestle & 50 & 57 & & \\
\hline Borden & 0 & 0 & & \\
\hline Chock & 0 & 0 & & \\
\hline$\chi^{2}$ statistic & $10.14^{\mathrm{a}}$ & $12.67^{\mathrm{a}}$ & & \\
\hline
\end{tabular}

size, then the number of entrants can be used as a proxy for expected size.

Returning to the econometric specification, I now estimate the probability that firm $i$ enters in position $P$ instead of positions $1, \ldots, P-1$ by,

$$
\begin{aligned}
& \operatorname{Pr}\left(q_{i p}, F ; \beta, \gamma\right) \\
& \quad=\prod_{p=2}^{P} F_{i P-p+1}\left[q_{i P}, \ldots, q_{i P-p+1}, H, F ; \beta, \gamma\right]
\end{aligned}
$$

where

$$
\begin{aligned}
& F_{i P}\left[q_{i 1}, \ldots, q_{i P}, H, F ; \beta, \gamma\right] \\
& \quad=\exp \left(q_{i P} H \beta+\gamma F\right) /\left[\sum_{p=1}^{P} \exp \left(q_{i p} H \beta+\gamma F\right)\right] .
\end{aligned}
$$

In this case $H$ is a dummy variable which is equal to one if two or more firms entered with a new product during the round firm $i$ entered at position $p . H$ is equal to zero otherwise. If the estimated $\beta$ 's are positive and significant, then the greater the expected market size, the greater is the probability that a low capital firm will enter early. The results of this are presented in table 7.

The results are consistent with the third hypothesis across the three industries. The estimated coefficients from the pooled results are positive and significant for the first, second, third, and fourth entry positions. The same holds true in the beer and soft drink industries. In the coffee industry the result holds for the first, second, and third entry positions.

To assess this result's robustness I used another proxy for expected market size, the first-year advertising expenditures for the product that led a 


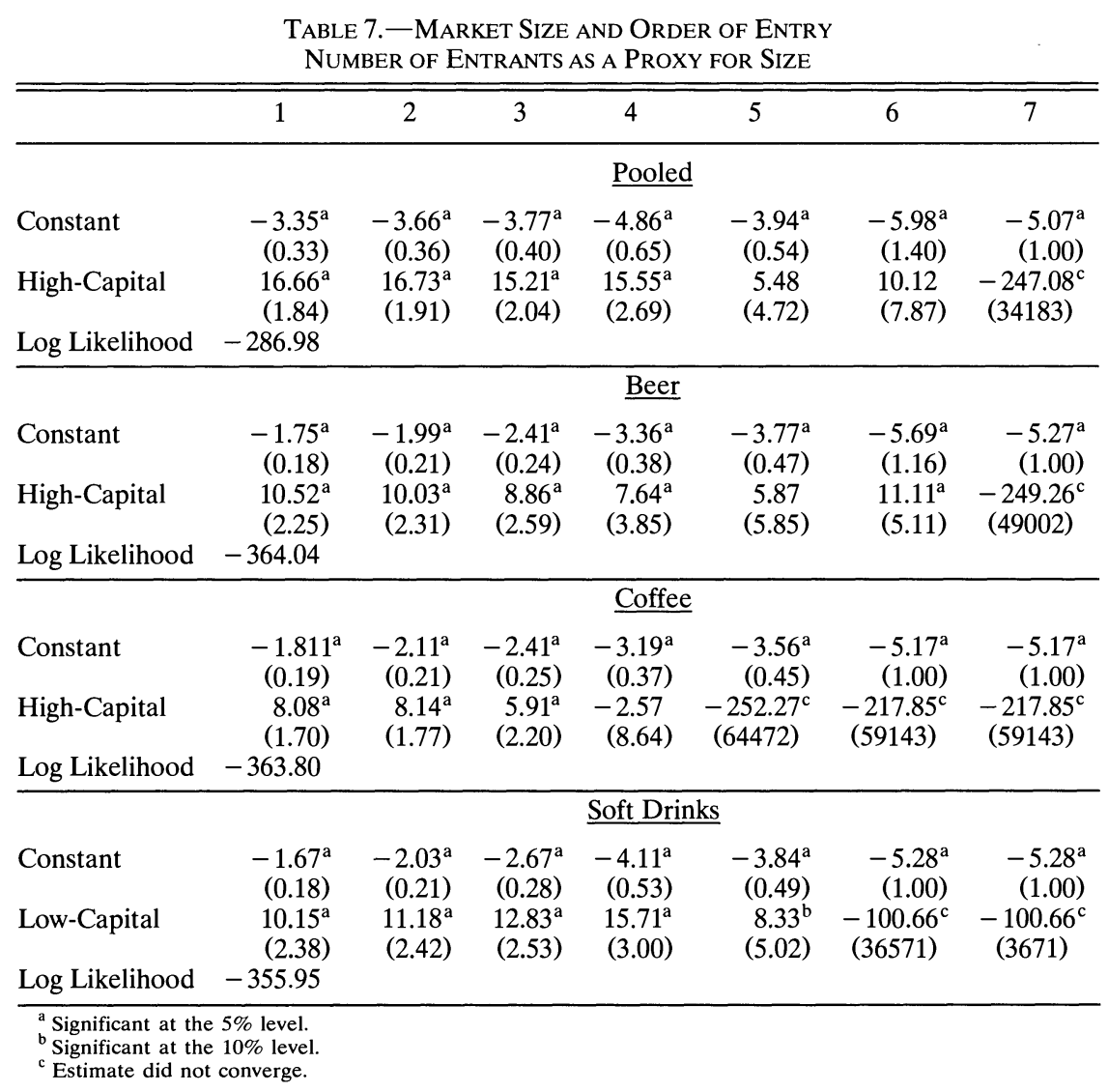

round. ${ }^{9}$ Each firm must decide how much to spend on advertising if it decides to introduce a new brand. Firms with the same information and brand capital should spend the same amount on advertising in a given segment. Thus controlling for brand capital, advertising expenditures should be proportional to expected market size.

I will first test the hypothesis using the rank ordered logit technique. Advertising data were obtained from Leading National Advertisers and adjusted for inflation. For each new product round I determined the real advertising expenditures for the first product in the round during its first year of introduction. Across all rounds the median value was $\$ 3.25$ million. I assume that market size was expected to be small in those

\footnotetext{
${ }^{9}$ If the product was introduced during the first three months of year $t$, I used the advertising expenditures for that product during year $t$; if the product was introduced later during year $t$, I used the first year advertising expenditures for the product during year $t+1$.
}

rounds with a first year advertising expense for first entry less than this, large in those above it.

In this case I estimated the same model as described above but $H$ is now equal to one if the first year advertising expense of the product leading the round is greater than the mean and zero otherwise. As before, from the above expression a likelihood function can be determined and MLE found for the $\beta$ 's and $\gamma$. The results are reported in table 8. In the pooled data set the coefficients for the first, second, third, and fourth entry positions are significantly larger for the high expected size markets than the low. This means that a low capital firm is more likely to enter first, the larger is the market's expected size.

The model is also estimated for each of the three industries separately using its own median first-year advertising expenditure. In the beer industry one finds that for all but the seventh entry position firms have a greater probability of entering the larger is the expected market size. In the 
coffee industry one finds this result for the first, second, and third entry positions. Again, the results are weaker in the soft drink industry. Only in the case of the third entry positions are the results consistent with the maintained hypothesis. The other coefficients, while the correct sign, are not significant.

As an additional test using this proxy for expected market size I estimated the following logit model:

$$
L E A D_{i s}=\beta_{1}+\beta_{2}(R E A L \$ A D)_{i s}+\epsilon_{i s} .
$$

The dependent variable, $L E A D$, was set equal to one if the firm with the highest share of capital brands in segment $s$ during the year round $i$ began was the first to introduce, zero otherwise.
REAL $\$ A D$ is the real first year advertising expenditure for the product that led round $i$ in segment $s$.

If the above model is estimated for each industry separately, the small number of observations provide limited empirical leverage, and so results are presented in table 9 using the entire pooled cross section. A logistic distribution is assumed for the dependent variable. The results from the pooled data and for the beer industry individually are significant at the 5\% level in a one tailed test, and the model does explain a substantial amount of the variation in the data as indicated by the percentage correct statistic. Firms with a low share of capital brands are thus more likely to lead a round when the expected market size is

TABle 8.-MARKET Size AND ORder of ENTRY Advertising as a ProXy For Size

\begin{tabular}{|c|c|c|c|c|c|c|c|}
\hline & 1 & 2 & 3 & 4 & 5 & 6 & 7 \\
\hline & \multicolumn{7}{|c|}{$\underline{\text { Pooled }}$} \\
\hline Constant & $\begin{array}{r}-2.09^{\mathrm{a}} \\
(0.23)\end{array}$ & $\begin{array}{r}-2.23^{\mathrm{a}} \\
(0.24)\end{array}$ & $\begin{array}{r}-2.84^{\mathrm{a}} \\
(0.31)\end{array}$ & $\begin{array}{r}-4.07^{\mathrm{a}} \\
(0.53)\end{array}$ & $\begin{array}{r}-3.76^{\mathrm{a}} \\
(0.52)\end{array}$ & $\begin{array}{c}-5.66^{\mathrm{a}} \\
(1.26)\end{array}$ & $\begin{array}{r}-5.02^{\mathrm{a}} \\
(1.00)\end{array}$ \\
\hline High-Capital & $\begin{array}{r}8.34^{\mathrm{a}} \\
(1.41)\end{array}$ & $\begin{array}{r}7.28^{\mathrm{a}} \\
(1.52)\end{array}$ & $\begin{array}{r}8.21^{\mathrm{a}} \\
(1.65)\end{array}$ & $\begin{array}{r}9.18^{\mathrm{a}} \\
(2.14)\end{array}$ & $\begin{array}{c}3.85 \\
(3.97)\end{array}$ & $\begin{array}{c}6.96 \\
(6.22)\end{array}$ & $\begin{array}{c}-188.89^{c} \\
(34129)\end{array}$ \\
\hline \multirow[t]{2}{*}{ Log Likelihood } & -318.82 & & & & & & \\
\hline & & & & Beer & & & \\
\hline Constant & $\begin{array}{c}-1.73 \\
(0.19)\end{array}$ & $\begin{array}{r}-1.95^{\mathrm{a}} \\
(0.21)\end{array}$ & $\begin{array}{r}-2.41^{\mathrm{a}} \\
(0.26)\end{array}$ & $\begin{array}{c}-3.41 \\
(0.41)\end{array}$ & $\begin{array}{r}-3.67^{\mathrm{a}} \\
(0.47)\end{array}$ & $\begin{array}{r}-5.57^{\mathrm{a}} \\
(1.14)\end{array}$ & $\begin{array}{r}-5.17^{\mathrm{a}} \\
(1.00)\end{array}$ \\
\hline High-Capital & $10.24^{\mathrm{a}}$ & $\begin{array}{c}9.26^{\mathrm{a}} \\
(253)\end{array}$ & $9.15^{\mathrm{a}}$ & $8.22^{\mathrm{a}}$ & $6.0^{\mathrm{a}}$ & $11.01^{\mathrm{a}}$ & $-99.45^{c}$ \\
\hline \multirow[t]{2}{*}{ Log Likelihood } & -332.42 & & & & & & \\
\hline & & & & Coffee & & & \\
\hline Constant & $\begin{array}{r}-1.56^{\mathrm{a}} \\
(0.18)\end{array}$ & $\begin{array}{r}-1.84^{\mathrm{a}} \\
(0.20)\end{array}$ & $\begin{array}{r}-2.34^{\mathrm{a}} \\
(0.25)\end{array}$ & $\begin{array}{r}-3.18^{\mathrm{a}} \\
(0.39)\end{array}$ & $\begin{array}{r}-3.52^{\mathrm{a}} \\
(0.45)\end{array}$ & $\begin{array}{r}-5.13^{\mathrm{a}} \\
(1.00)\end{array}$ & $\begin{array}{r}-5.13^{\mathrm{a}} \\
(1.00)\end{array}$ \\
\hline High-Capital & $\begin{array}{r}5.53^{\mathrm{a}} \\
(2.09)\end{array}$ & $\begin{array}{r}5.11^{\mathrm{a}} \\
(229)\end{array}$ & $\begin{array}{r}5.74^{\mathrm{a}} \\
(246)\end{array}$ & $\begin{array}{c}-253.95^{c} \\
(85446)\end{array}$ & $\begin{array}{l}-246.46^{c} \\
(82442)\end{array}$ & $-217.43^{c}$ & $-217.43^{c}$ \\
\hline \multirow[t]{2}{*}{ Log Likelihood } & -342.05 & & & & & & \\
\hline & \multicolumn{7}{|c|}{ Soft Drinks } \\
\hline Constant & $\begin{array}{r}-1.51^{\mathrm{a}} \\
(0.18)\end{array}$ & $\begin{array}{c}-1.80^{\mathrm{a}} \\
(0.20)\end{array}$ & $\begin{array}{c}-2.36^{\mathrm{a}} \\
(0.26)\end{array}$ & $\begin{array}{r}-3.91^{\mathrm{a}} \\
(0.53)\end{array}$ & $\begin{array}{r}-3.70^{\mathrm{a}} \\
(0.49)\end{array}$ & $\begin{array}{r}-5.14^{\mathrm{a}} \\
(1.00)\end{array}$ & $\begin{array}{r}-5.14^{\mathrm{a}} \\
(1.00)\end{array}$ \\
\hline Low-Capital & $\begin{array}{c}3.44 \\
(2.22)\end{array}$ & $\begin{array}{c}3.19^{\mathrm{a}} \\
(2.50)\end{array}$ & $\begin{array}{c}5.67^{\mathrm{a}} \\
(2.42)\end{array}$ & $\begin{array}{l}10.71^{\mathrm{a}} \\
(2.77)\end{array}$ & $\begin{array}{c}4.54 \\
(4.74)\end{array}$ & $\begin{array}{c}-112.51^{c} \\
(57234)\end{array}$ & $\begin{array}{c}-112.51^{\mathrm{c}} \\
(57234)\end{array}$ \\
\hline \multirow[t]{2}{*}{ Log Likelihood } & -340.87 & & & & & & \\
\hline & & & & Pooled & & & \\
\hline Constant & $\begin{array}{r}-4.31^{\mathrm{a}} \\
(0.47)\end{array}$ & $\begin{array}{c}-3.59^{\mathrm{a}} \\
(0.41)\end{array}$ & $\begin{array}{r}-3.81^{\mathrm{a}} \\
(0.46)\end{array}$ & $\begin{array}{c}-4.98^{\mathrm{a}} \\
(0.76)\end{array}$ & $\begin{array}{r}-3.56^{\mathrm{a}} \\
(0.54)\end{array}$ & $\begin{array}{r}-5.57^{\mathrm{a}} \\
(1.39)\end{array}$ & $\begin{array}{r}-4.76^{\mathrm{a}} \\
(1.00)\end{array}$ \\
\hline Low-Capital & $\begin{array}{l}13.71^{\mathrm{a}} \\
(1.79)\end{array}$ & $\begin{array}{l}10.63^{\mathrm{a}} \\
(1.72)\end{array}$ & $\begin{array}{r}7.91^{\mathrm{a}} \\
(2.19)\end{array}$ & $\begin{array}{c}5.26 \\
(4.88)\end{array}$ & $\begin{array}{c}-305.75^{c} \\
(47451)\end{array}$ & $\begin{array}{r}-261.86 \\
(56663)\end{array}$ & $\begin{array}{c}-284^{c} \\
(57507)\end{array}$ \\
\hline High-Capital & $\begin{array}{l}16.95^{\mathrm{a}} \\
(2.16)\end{array}$ & $\begin{array}{l}13.68^{\mathrm{a}} \\
(2.11)\end{array}$ & $\begin{array}{l}13.76^{\mathrm{a}} \\
(2.24)\end{array}$ & $\begin{array}{l}15.06^{\mathrm{a}} \\
(2.92)\end{array}$ & $\begin{array}{c}4.20 \\
(4.50)\end{array}$ & $\begin{array}{c}8.54 \\
(7.76)\end{array}$ & $\begin{array}{c}-206.97^{c} \\
(44512)\end{array}$ \\
\hline Log Likelihood & -265.03 & & & & & & \\
\hline
\end{tabular}


Table 9.-Equation (2) Estimated for Each Industry AND ALL INDUSTRIES

\begin{tabular}{|c|c|c|c|c|}
\hline & Beer & Coffee & Soft Drinks & All \\
\hline Constant & $\begin{array}{l}1.87 \\
(2.2)\end{array}$ & $\begin{array}{c}1.07 \\
(0.99)\end{array}$ & $\begin{array}{c}0.95 \\
(1.03)\end{array}$ & $\begin{array}{c}0.75 \\
(1.74)\end{array}$ \\
\hline Real \$Ad & $\begin{array}{c}-0.117 \\
(1.71)\end{array}$ & $\begin{array}{c}-0.45 \\
(1.53)\end{array}$ & $\begin{array}{c}-0.36 \\
(1.43)\end{array}$ & $\begin{array}{c}-0.12 \\
(1.91)\end{array}$ \\
\hline $\begin{array}{c}\text { Percentage } \\
\text { Correct } \\
N=43 \\
\sigma=7.04 \\
\mu=5.29\end{array}$ & 82.3 & 83.3 & 71.4 & 62.8 \\
\hline
\end{tabular}

large, consistent with the third maintained hypothesis.

\section{Conclusions}

This paper began by observing persistence of market shares in industries with high advertising expenditures. While there has been much research on first mover advantages and brand proliferation, these theories do not explain why some firms remain share leaders even as tastes change or new information about them becomes available. Brand capital offers a possible explanation for this phenomenon. As firms acquire new information, small and large markets for new product varieties open. The firm with the greatest brand capital is most likely to occupy all new markets, and firms with less brand capital occupy large ones. Thus, the high brand capital firm can hold on to its lead.

In the beer and coffee industries, the firm with the higher share of capital brands is most likely to enter first with a new product in response to new information. Moreover, in the beer industry, the firm that enters second has a higher share of capital brands than those that enter later. In the coffee industry, firms that enter first, second or third have more high capital brands than those that enter later. These results offer some support for the brand capital hypotheses. Results from the soft drink industry offer somewhat less support. In the soft drink industry, the firm with the highest share of capital brands was not the most likely to enter first. This is largely due to the unexplained strategy of one firm, Royal Crown. This strategy has not improved the firm's performance.

\section{REFERENCES}

Aaker, David A., Managing Brand Equity (New York: Free Press, 1991).

Aaker, David, and Kevin Keller, "Consumer Evaluations of Brand Extensions," Journal of Marketing 54 (1990), 27-41.

Brander, James A., and Jonathan Eaton, "Product Line Rivalry," American Economic Review 74 (1984), 323-334.

Elzinga, Kenneth G., "The Beer Industry,” in W. Adams (ed.), The Structure of American Industry (New York: Macmillan, 1986), 128-161.

Hausman, Jerry, "Specification Tests in Econometrics," Econometrica 46 (1987), 1251-1271.

Hausman, Jerry, and Paul Ruud, "Specifying and Testing Econometric Models for Rank-Ordered Data," Journal of Econometrics 34 (1987), 83-104.

Raubitschek, Ruth, "Hitting the Jackpot: Product Proliferation by Multiproduct Firms under Uncertainty," International Journal of Industrial Organization 6 (1988), 469-488.

Reinganum, Jennifer, "Uncertain Innovation and the Persistence of Monopoly," American Economic Review 73 (1983), 741-748.

Robinson, William T., and Claes Fornell, "Sources of Market Pioneer Advantages in Consumer Goods Industries," Journal of Marketing Research 23 (1985), 305-317.

Schmalensee, Richard, "Entry Deterrence in the RTE Cereal Industry," Bell Journal of Economics 9 (1978), 305-327. , "Product Differentiation Advantages of Pioneering Brands," American Economic Review 72 (1982), 349-365.

Sullivan, Mary, "Brand Extensions: When to Use Them," Management Science 38 (1992), 793-805.

Sutton, John, Sunk Costs and Market Structure (Cambridge, MA: MIT Press, 1991).

Urban, Glenn L. et al., "Market Share Rewards to Pioneering Brands: An Empirical Analysis and Strategic Implications," Management Science 32 (1986), 645-659.

Wernerfelt, Birger, "Umbrella Branding as a Signal of New Product Quality: An Example of Signaling by Posting a Bond," Rand Journal of Economics 19 (1988), 458-466.

Wernerfelt, Birger, and David E. Sappington, "To Brand or Not to Brand? A Theoretical and Empirical Question," Journal of Business 58 (1985), 279-293. 